Brit. J. vener. Dis. (1964), 40, 198.

\title{
LOCAL FUNGICIDE USED CONCOMITANTLY WITH "FLAGYL" IN TRICHOMONAL INFECTION*
}

\author{
BY
}

M. MARY BEVERIDGE

Royal Hospital, Sheffield

Following treatment of 102 women prisoners with "Flagyl" (metronidazole) Keighley (1962) found Monilia present in 29; Brochin and Buxton (1963) studied 69 patients under treatment with metronidazole and found four (5.7 per cent.) with moniliasis before trichomonal treatment and three more $(4.4$ per cent.) in the post-treatment period. Csonka (1963), using direct microscopy, found Monilia in two of 101 women with trichomonal . vaginitis in the pre-treatment phase and a further eleven cases only after treatment with "Flagyl". Other papers discussing metronidazole therapy and mentioning moniliasis do not report the incidence of moniliasis before and after treatment, although in some we are left in no doubt that the fungus was present after treatment (e.g. Moffet and McGill, 1960; Whitehouse and Porteous, 1962). In some patients the symptoms were severe.

In Sheffield VD clinics, 4 per cent. of women had C. albicans in the vagina when they were first found to have trichomonal vaginitis, and Monilia were found in a further 19 per cent. during the follow-up period (Beveridge, 1962). It was then suggested that a local fungicide prescribed concomitantly with

* Received for publication March 9, 1964.
Flagyl should be considered. This short paper reports the results of following this suggestion.

\section{Material}

The group studied comprised 100 consecutive patients with trichomonal vaginitis seen at the Royal Hospital and Royal Infirmary, Sheffield, during 1962 and 1963. Their ages, marital status, and reasons for attending are shown in Table I.

The high percentage of teenagers is in part accounted for by the fact that this group included girls from the local remand home and a local approved school, and this also accounts in part for the marital status distribution.

The 62 who attended for "other reasons" include women who came with a variety of symptoms and a proportion of remand home and approved school girls who required statutory examination. Some of these had symptoms and some did not.

\section{Method and Management}

At each visit patients were examined for gonococcal infection by smear and culture; vaginal secretion was examined by dark-ground microscopy for $T$. vaginalis; vaginal smears were prepared and stained with Gram's stain. The diagnosis of Candida albicans was made from these latter specimens by recognizing the Gram-positive hyphae or buds of the fungus. The hyphae of $C$. albicans must be differentiated from the Gram-positive lactobacillus. Hyphae are irregular in length, usually broader

TABLE I

PARTICULARS OF 100 CONSECUTIVE CASES OF TRICHOMONAL VAGINITIS

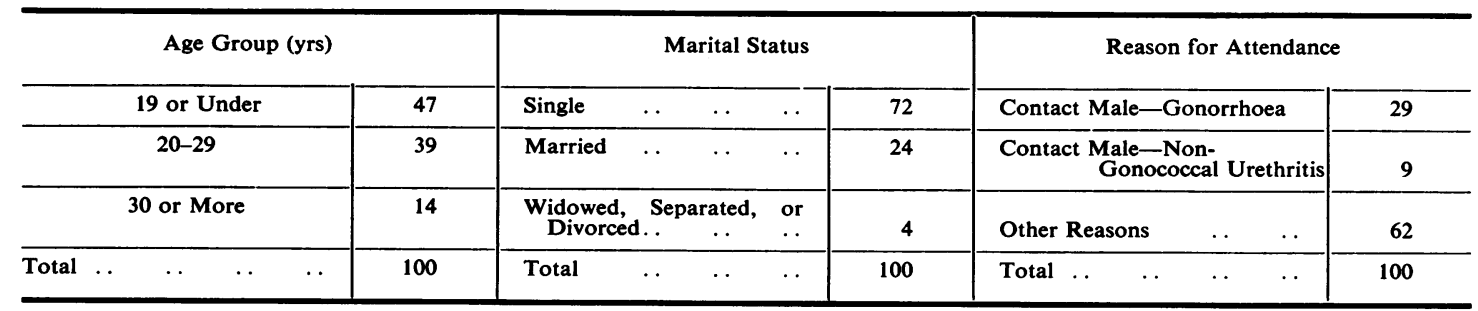


TABLE II

FINDINGS AND FOLLOW-UP

\begin{tabular}{|c|c|c|c|c|c|c|c|c|c|c|c|}
\hline \multicolumn{4}{|c|}{ Presenting Symptom } & \multicolumn{4}{|c|}{ Bacteriology at First Examination } & \multicolumn{4}{|c|}{ Length of Follow-up } \\
\hline $\begin{array}{l}\text { Vaginal discharge } \\
\text { Vulvar irritation } \\
\text { Other complaints } \\
\text { No complaints }\end{array}$ & $\begin{array}{l}\cdots \\
\cdots \\
\cdots\end{array}$ & $\begin{array}{l}\cdots \\
\cdots \\
\cdots\end{array}$ & $\begin{array}{r}34 \\
7 \\
3 \\
56\end{array}$ & $\begin{array}{l}\text { T. vag } \\
T . \text { vag } \\
T . \text { vag } \\
T . \text { va } \\
\text { C. a }\end{array}$ & $\begin{array}{l}s \\
s+g \\
s+c \\
\text { ans }\end{array}$ & $\begin{array}{l}\text { ococci } \\
\text { albicans } \\
\text { onococci } \\
\ldots\end{array}$ & $\begin{array}{r}58 \\
38 \\
3 \\
1\end{array}$ & $\begin{array}{l}2 \text { wks } \\
1 \text { mth } \\
2 \text { mths } \\
3 \text { mths or } \\
\text { Defaulted }\end{array}$ & $\begin{array}{cc}\cdots & \ldots \\
\cdots & \cdots \\
\text { more } & \cdots \\
\text { after one } & \text { visit }\end{array}$ & $\begin{array}{l}\cdots \\
\cdots \\
\cdots \\
\cdots\end{array}$ & $\left.\begin{array}{l}89 \\
59 \\
41 \\
18\end{array}\right\} 89$ \\
\hline Total ... & . & . & 100 & Total & . & . & 100 & Total ... & . & $\ldots$ & 100 \\
\hline
\end{tabular}

than the bacillus and with rounded ends. Not infrequently they show spore holes. The lacto-bacillus, on the other hand, is fairly regular in length with almost square ends, Confusion may arise when bacilli are found end to end or are terminally bulbous, giving the appearance of hyphae.

A follow-up of 3 months was the aim in all cases. Twice-weekly or weekly examinations were called for in the first post-treatment month and if progress was satisfactory, monthly visits were arranged thereafter.

The routine of therapy was-Flagyl $200 \mathrm{mg}$. three times daily for 7 days with one Nystatin pessary of 100,000 units nightly for the same period. Those requiring treatment for gonorrhoea were usually given penicillin.

\section{Results}

The presenting symptoms and laboratory findings, and the length of follow-up are shown in Table II.

C. albicans was present in 4 per cent. initially, but a further seven cases were found during follow-up, that is between 5 and 60 days after treatment was started. Two showed Monilia at 5 days, one at 8 days, two at 21 days, and one each at 30 and 60 days. Only two of the seven complained of symptoms referable to fungus injection. Three of the seven had received antibiotic therapy initially. The cure rate with Flagyl was 94 per cent. at completion of followup. None of those who developed moniliasis failed to respond to Flagyl. Six of the seven were married women but what part, if any, this plays in the condition is unknown.

\section{Discussion}

In my first paper (Beveridge, 1962), it was suggested that the trichomonal vaginitis might mask the presence of the fungus and that the relatively high incidence of post-treatment moniliasis (19 per cent.) was an index of cure rather than a side-effect. It was hoped completely to forestall the appearance of the fungus by simple local treatment. That there has been some reduction in the incidence of post-treatment moniliasis is in no doubt, but a fall from 19 to 7 per cent. is felt to be disappointing.
Were a fungicidal drug discovered which, given by mouth, was active systemically against $C$. albicans, its incorporation with metronidazole in an oral tablet would be of value.

\section{Summary}

100 women with trichomonal vaginitis were treated with Flagyl (metronidazole) $200 \mathrm{mg}$. three times daily for 7 days. One Nystatin pessary of 100,000 units nightly for the same week was also prescribed.

The régime reduced the post-treatment incidence of fungus infection from 19 to 7 per cent., but this result is considered to be disappointing.

A further attempt to prevent post-treatment moniliasis is suggested.

My thanks are due to Dr R. S. Morton for encouragement and helpful criticism.

\section{REFERENCES}

Beveridge, M. M. (1962). Brit. J. vener. Dis., 38, 220.

Brochin, M., and Buxton, C. L. (1963). New Engl. J. Med., 268, 1400.

Csonka, G. W. )1963). Brit. J. vener. Dis., 39, 258.

Keighley, E. E. (1962). Brit. med. J., 2, 93.

Moffett, M., and McGill, M. I. (1960). Ibid. 2, 910.

Whitehouse, W. L., and Porteous, C. R. (1962). Lancet, 1, 506.

\section{Un fongicide topique employé en même temps que} le "Flagyl" en cas d'infection trichomonale

\section{RÉSUMÉ}

A 100 femmes atteintes de vaginite trichomonale on donna $200 \mathrm{mg}$. de "Flagyl" (métronidazole) trois fois par jour pendant 7 jours, et en même temps un pessaire de 100.000 unités de Nystatin chaque soir.

Ce régime réduit l'incidence d'infection fongueuse de 19 à $7 \%$, mais il faut regarder ce résultat comme peu satisfaisant. 